\title{
Seabird seasonal trophodynamics: isotopic patterns in a community of Pacific alcids
}

\author{
W. E. Davies ${ }^{1,3}$, J. M. Hipfner ${ }^{1}$, K. A. Hobson ${ }^{2}$, R. C. Ydenberg ${ }^{1, *}$ \\ ${ }^{1}$ Centre for Wildlife Ecology, Simon Fraser University, 8888 University Blvd., Burnaby, British Columbia V5A 1S6, Canada \\ ${ }^{2}$ Environment Canada, 11 Innovation Blvd., Saskatoon, Saskatchewan S7N 3H5, Canada \\ ${ }^{3}$ Present address: Department of Ecology \& Evolutionary Biology, University of Toronto, 25 Willcocks Street, Toronto, \\ Ontario M5S 3B2, Canada
}

\begin{abstract}
We measured $\delta^{15} \mathrm{~N}$ and $\delta^{13} \mathrm{C}$ values in the blood of breeding adults and nestlings of 5 species of alcids at Triangle Island, British Columbia, to estimate the extent to which these seabirds alter their foraging ecology across successive breeding stages. Considerable intraspecific (stage-tostage) and interspecific variation was found. Two species-common murre Uria aalge and pigeon guillemot Cepphus columba-fed consistently at high trophic levels (i.e. diets of fish) in inshore or benthically linked habitats. The foraging ecology of 3 others-Cassin's auklet Ptychoramphus aleuticus, rhinoceros auklet Cerorhinca monocerata and tufted puffin Fratercula cirrhata-was more variable. Tufted puffins exhibited especially dramatic trophic and habitat shifts between early and late-season diets. With the exception of tufted puffin, the diet of provisioning adults differed from that fed to their nestlings. Trophic level of the community as a whole increased as the season progressed due to the combination of trophic shifting by rhinoceros auklets and tufted puffins, and earlier breeding by zooplanktivorous Cassin's auklets than by piscivorous murres and guillemots. Our results contribute to a growing body of evidence that marine bird species exhibit considerable flexibility in their foraging behaviour and also shed new light on seasonal patterns in the trophic relations within marine bird communities.
\end{abstract}

KEY WORDS: Alcids $\cdot$ Breeding stages $\cdot{ }^{13} \mathrm{C} \cdot$ Community ecology $\cdot$ Foraging ecology $\cdot{ }^{15} \mathrm{~N} \cdot$ Trophic relationships $\cdot$ Stable isotope analysis

Resale or republication not permitted without written consent of the publisher

\section{INTRODUCTION}

Seabirds play critical roles in the transfer of energy and nutrients within marine ecosystems and also between marine and terrestrial ecosystems. Despite decades of intensive study, however, key facets of the reproductive ecology of marine birds remain poorly understood. In particular, there is a notable discrepancy between the depth of our understanding of oncolony versus off-colony (including the non-breeding season) facets of their biology, stemming from the fact that seabirds are relatively easy to study on land, but much more difficult to study at sea. As a result, the question of how the foraging ecology of marine birds is adaptively related to the form and function of their reproductive traits remains, to a large extent, unresolved.

In recent years, new techniques (stable isotope analysis, fatty acid analysis) have provided novel insights into previously less-accessible facets of vertebrate foraging ecology (Kelly 2000). Stable isotopic analysis (SIA) is based on the fact that organisms incorporate into their body tissues the isotopic signals of the environments in which they live, as well as the foods they eat. This analytical approach has a particularly rich history in marine ecological research (Hobson et al. 1994) and has revealed that some marine birds considered to be narrow trophic specialists actually utilise a surprisingly wide range of trophic levels and marine habitats while breeding (Forero et al. 2004), with vari- 
ation found among colonies (Forero et al. 2002), subcolonies (Hipfner et al. 2007), foraging trip duration (Cherel et al. 2005), age (Hodum \& Hobson 2000) and gender (Forero et al. 2005).

To date, however, few studies based on SIA have examined the extent to which marine birds alter their foraging behaviour across discrete breeding stages (but see Quillfeldt et al. 2005). Flexible foraging behaviour could be an important mechanism by which seabirds meet the unique nutritional demands of each stage and, within the larger ecological context set out by the seasonal progression of events, in the marine environment (Levinton 2001). While several SIA studies have documented the trophic relationships among the component members of seabird communities (Hobson et al. 1994, Forero et al. 2004), few have considered temporal variation in the relationships across the community as a whole (Sydeman et al. 1997, Cherel et al. 2008). Combined with more conventional 'snapshot' studies, the examination of seasonal trophodynamics could provide a more comprehensive understanding of factors that shape and constrain the life histories of this group of marine organisms. Such approaches could also improve our ability to understand and predict species-level and community-level responses to natural and anthropogenic climate change, which is having dramatic effects on marine trophic interactions (Edwards \& Richardson 2004).

We used SIA on blood samples taken from breeding adults of 5 species of seabirds belonging to the family Alcidae, to track trophic level (based on $\delta^{15} \mathrm{~N}$ measurements) and habitat use (i.e. inshore vs. offshore foodwebs based on $\delta^{13} \mathrm{C}$ measurements) from the prelaying through the incubation and offspring-provisioning periods. In addition, we collected prey species delivered by adults to nestlings, including both zooplankton and fish, and used this conventional dietary information, in combination with the isotopic values in nestling blood, to calculate discrimination factors appropriate to our study site and study species. As we will show, this proved to be necessary, since published discrimination values did not result in realistic solutions to simple isotopic mixing models.

Our main objective was to quantify the extent of trophic and habitat shifting that these species exhibit from one breeding stage to the next. Secondarily, we also used intraspecific information to investigate seasonal variation in trophic level and habitat use across the community as a whole. Previous studies suggest that alcid communities tend to converge on fish-feeding late in the season, based on nestling diets, and this has been used to make inference about the ecological factors that structure seabird communities (Ainley \& Boekelheide 1990, Hatch \& Hatch 1990). By bringing together isotopic measurements of self-feeding and provisioning adults with those of offspring, we aimed to provide a uniquely comprehensive view.

\section{MATERIALS AND METHODS}

Triangle Island (120 ha; $\left.50^{\circ} 52^{\prime} \mathrm{N}, 1^{\circ} 9^{\circ} 05^{\prime} \mathrm{W}\right)$ lies $46 \mathrm{~km}$ off the northwest tip of Vancouver Island, British Columbia, Canada, in shallow $(<200 \mathrm{~m})$ waters some $25 \mathrm{~km}$ from the edge of the continental shelf. The site lies within the transitional zone between the upwelling-driven California Current ecosystem to the south and the downwelling-driven Alaska Gyre system to the north. Approximately 1.2 million alcids breed on Triangle Island, including sizeable populations of 5 species: common murre Uria aalge, pigeon guillemot Cepphus columba, Cassin's auklet Ptychoramphus aleuticus, and 2 species of puffins, rhinoceros auklet Cerorhinca monocerata and tufted puffin Fratercula cirrhata. Two other alcids, thick-billed murre Uria lomvia and horned puffin Fratercula corniculata, typically associated with arctic and subarctic marine environments, breed in very small numbers on Triangle Island (Rodway 1991).

Field sampling protocol. Sampling took place between late March and late August in 2002, a year in which oceanographic conditions in the vicinity of Triangle Island, including both abiotic and biotic factors, were close to long-term averages (Mackas et al. 2007).

Prey items: We collected prey items delivered to Cassin's auklet and rhinoceros auklet nestlings at the colony, using standard methods (Hipfner et al. 2004). Provisioning Cassin's auklets were intercepted in pheasant nets set up at the base of the breeding colony, removed by hand and induced to regurgitate food loads into plastic bottles. From these samples, small subsamples for SIA were removed and frozen at $-10^{\circ} \mathrm{C}$. Later examination (Hipfner 2008) revealed that individual samples were dominated $(\geq 64 \%$ by wet mass) by of 1 of 3 types of zooplankton: copepods (almost exclusively Neocalanus cristatus), euphausiids (mainly Thysanoessa spinifera) and ichthyoplankton (unidentified age $0^{+}$larval and juvenile fish; hereafter 'juvenile fish'). We selected 5 regurgitant samples dominated by each of these 3 prey types for SIA.

Provisioning rhinoceros auklets were caught on the ground with long-handled fishing nets, and the whole prey items they carried (age $0^{+}$to adult Pacific sandlance Ammodytes hexapterus, post-smolt Pacific salmon Oncorhynchus spp., age $0^{+}$rockfish Sebastes spp., adult Pacific saury Cololabis saida, squid of unknown species) were collected. All prey items were weighed, measured and identified in the field. Muscle samples ( 1 g) were cut from the mid-body, placed into 
vials and frozen at $-10^{\circ} \mathrm{C}$. Squid were processed in the same way, with muscle removed from the mantle.

Seabird blood samples: Blood (0.5 to $1.0 \mathrm{ml}$ ) was drawn from the brachial veins of adults of each of the 5 species caught by a variety of standard methods (in nets and noose carpets, or with noose poles) during each of the prelaying, incubation and provisioning periods. Adults were released immediately after being sampled. Blood samples (ca. $0.5 \mathrm{ml}$ ) were collected from nestlings at approximately $3 \mathrm{wk}$ of age. By that age, nestlings in all species weighed about 3 to 6 times their hatching mass, and elements derived from eggs should have been highly diluted by those in prey delivered by adults and should represent a very small fraction of the elemental composition of blood. Blood was placed into vials and frozen at $-10^{\circ} \mathrm{C}$.

Stable isotope analyses. Sample processing: All samples were shipped frozen to the Environment Canada laboratory of KAH. Blood and prey samples were freeze-dried and powdered. Lipids were extracted from prey samples by successively rinsing in a 2:1 chloroform:methanol solution, then air-drying under a fume hood. Stable-carbon and -nitrogen isotope assays were performed on $1 \mathrm{mg}$ sub-samples of powdered material at the stable isotope facility of the Department of Soil Science, University of Saskatchewan. Samples were first loaded into tin cups and combusted in a Robo-Prep elemental analyzer at $1200^{\circ} \mathrm{C}$. The resultant $\mathrm{CO}_{2}$ and $\mathrm{N}_{2}$ gases were separated and analyzed using an interfaced Europa 20:20 continuous-flow isotope ratio mass spectrometer, with every fifth sample separated by 2 (albumin) laboratory standards. Results were reported in delta notation in parts per thousand (\%) relative to air $\left(\delta^{15} N\right)$ and Vienna PeeDee Belemnite $\left(\delta^{13} \mathrm{C}\right)$. Based on replicate measurements of albumin standards, measurement precision (SD) for $\delta^{13} \mathrm{C}$ and $\delta^{15} \mathrm{~N}$ values was estimated to be \pm 0.1 and $\pm 0.3 \%$, respectively. Samples sizes for all prey and seabird tissues are reported in Table 1.

Discrimination factors: We used $\delta^{13} \mathrm{C}$ discrimination factors from the literature because carbon fractionates only weakly in food webs (Kelly 2000). For blood samples, we used Cherel et al.'s (2005) average for 4 fisheating seabirds $(0.0 \%)$. We estimated the $\delta^{15} \mathrm{~N}$ discrimination factor directly by comparing the value measured in the prey delivered to nestlings with that measured in nestling blood.

Table 1. Carbon and nitrogen stable isotopic values in prey and seabird tissues. (mean and SE)

\begin{tabular}{|c|c|c|c|c|c|c|}
\hline \multirow[t]{2}{*}{ Species } & \multirow[t]{2}{*}{ Stage/Tissue type } & \multirow[t]{2}{*}{$\mathrm{N}$} & \multicolumn{2}{|c|}{$\delta^{13} \mathrm{C}(\%)$} & \multicolumn{2}{|c|}{$\delta^{15} \mathrm{~N}(\% \circ)$} \\
\hline & & & Mean & SE & Mean & SE \\
\hline Thysanoessa spinifera & Whole & 5 & -18.58 & 0.42 & 11.09 & 0.33 \\
\hline Neocalanus cristatus & Whole & 5 & -20.13 & 0.42 & 11.36 & 0.33 \\
\hline Juvenile fish & Whole & 5 & -17.64 & 0.42 & 11.73 & 0.33 \\
\hline Rockfish & Muscle & 10 & -17.85 & 0.30 & 13.13 & 0.23 \\
\hline Squid & Muscle & 2 & -21.95 & 0.66 & 13.41 & 0.53 \\
\hline Sandlance & Muscle & 10 & -17.09 & 0.30 & 13.65 & 0.23 \\
\hline Salmon spp. & Muscle & 10 & -19.59 & 0.30 & 14.00 & 0.23 \\
\hline Pacific saury & Muscle & 10 & -20.36 & 0.30 & 14.31 & 0.23 \\
\hline Common murre & Prelaying blood & 15 & -17.41 & 0.11 & 15.10 & 0.11 \\
\hline \multirow{3}{*}{ Uria aalge } & Incubation blood & 14 & -17.07 & 0.12 & 14.96 & 0.11 \\
\hline & Provisioning blood & 15 & -17.00 & 0.11 & 15.31 & 0.11 \\
\hline & Nestling blood & 17 & -17.72 & 0.11 & 14.24 & 0.10 \\
\hline Pigeon guillemot & Prelaying blood & 12 & -16.56 & 0.13 & 14.91 & 0.12 \\
\hline \multirow[t]{2}{*}{ Cepphus columba } & Incubation blood & 2 & -16.86 & 0.31 & 14.99 & 0.29 \\
\hline & Nestling blood & 2 & -17.14 & 0.31 & 15.30 & 0.29 \\
\hline Cassin's auklet & Prelaying blood & 15 & -17.64 & 0.11 & 12.93 & 0.11 \\
\hline \multirow[t]{3}{*}{ Ptychoramphus aleuticus } & Incubation blood & 15 & -18.71 & 0.11 & 12.41 & 0.11 \\
\hline & Provisioning blood & 15 & -19.15 & 0.11 & 12.36 & 0.11 \\
\hline & Nestling & 14 & -19.28 & 0.12 & 12.92 & 0.11 \\
\hline Rhinoceros auklet & Prelaying blood & 14 & -18.60 & 0.12 & 13.54 & 0.11 \\
\hline \multirow[t]{3}{*}{ Cerorhinca monocerata } & Incubation blood & 15 & -17.63 & 0.11 & 13.90 & 0.11 \\
\hline & Provisioning blood & 15 & -18.63 & 0.11 & 14.57 & 0.11 \\
\hline & Nestling blood & 17 & -19.09 & 0.11 & 14.37 & 0.10 \\
\hline & Prelaying blood & 15 & -20.15 & 0.11 & 12.33 & 0.11 \\
\hline \multirow[t]{3}{*}{ Fratercula cirrhata } & Incubation blood & 15 & -19.48 & 0.11 & 12.53 & 0.11 \\
\hline & Provisioningblood & 15 & -18.75 & 0.11 & 14.11 & 0.11 \\
\hline & Nestling blood & 15 & -18.61 & 0.11 & 14.11 & 0.11 \\
\hline
\end{tabular}


Statistical tests. For each of the 5 study species, we created a single bivariate $\delta^{15} \mathrm{~N}-\delta^{13} \mathrm{C}$ plot to represent the trophic position $\left(\delta^{15} \mathrm{~N}\right.$ value $)$ and relative inshore-offshore location $\left(\delta^{13} \mathrm{C}\right.$ value) of the diet for adult blood at the 3 breeding stages (prelaying, incubation, provisioning), as well as nestling blood. We used Wilks' lambda to test for the equality of the centroid positions of bivariate isotope means, comparing across the 3 breeding stages for adults of each of the 5 species, and between provisioning adults and nestlings within species. We also compared isotopic centroids between nestlings to investigate whether fine-scale trophic segregation might be occurring among the 4 species known to provision primarily with fish (murre, guillemot and the 2 puffins).

\section{RESULTS}

\section{Direct estimation of discrimination factors}

Means of the uncorrected (i.e. no application of discrimination factors) stable isotope values are summarized in Table 1. Values for the prey species are shown in Fig. 1. Discrimination factors directly estimated by comparison of $\delta^{15} \mathrm{~N}$ values in nestling blood (predator values) to that in their prey (i.e. copepods, euphausiids and juvenile fish for Cassin's auklets Ptychoramphus aleuticus; sandlance, salmon, saury, rockfish and squid for rhinoceros auklets Cerorhinca monocerata) were $+1.5 \%$ for Cassin's auklets and $+0.6 \%$ for rhinoceros auklets. We used the average of these 2 estimates $(+1.1 \%)$ as our overall estimate of the blood-prey $\delta^{15} \mathrm{~N}$ discrimination factor (see Davies 2007 for a detailed description).

\section{Species-level analyses}

Isotopic values corrected by the appropriate discrimination factors for each of the 5 species are displayed in Fig. 1. In general, the standard deviations of estimates for both $\delta^{15} \mathrm{~N}$ and $\delta^{13} \mathrm{C}$ values are small, except for the pigeon guillemot Cepphus columba, for which we had the smallest and most incomplete samples. We are therefore generally confident about our estimates of the centroid positions. The small variation enabled us to detect highly significant variation in the combined $\delta^{15} \mathrm{~N}$ and $\delta^{13} \mathrm{C}$ values among the prelaying, incubation and provisioning stages in 4 of the 5 alcid species: common murres Uria aalge, Cassin's auklets Ptychoramphus aleuticus, rhinoceros auklets Cerorhinca monocerata and tufted puffins Fratercula cirrhata (all Wilks' lambda $\leq 0.286$, all $F \geq 17.84$, all $\mathrm{p}<$ 0.001). We could detect no difference in combined $\delta^{15} \mathrm{~N}$ and $\delta^{13} \mathrm{C}$ values between 12 prelaying and 2 incubating pigeon guillemots (Wilks' lambda $=0.88$, $F_{2,11}=0.75, \mathrm{p}=0.50$ ).

While considerable trophic and habitat shifting occurred across successive breeding stages, there was no pattern or extent of change common to all species. Two species, common murres and pigeon guillemots, at all stages fed on high trophic level prey (i.e. mean $\delta^{15} \mathrm{~N}$ value at all stages $\geq 14.9 \%$ ) captured in inshore or benthic habitats (i.e. mean $\delta^{13} \mathrm{C}$ value at all stages $\geq-17.4 \%$ ). Isotopic values were more variable in the 3 other species. Prior to laying, Cassin's auklets fed at an intermediate trophic level (mean $\delta^{15} \mathrm{~N}$ value $=$ $12.9 \%$ ), but thereafter at lower trophic levels during incubation and chick-rearing (mean $\delta^{15} \mathrm{~N}$ value $\leq 12.4 \%$ ). This species also fed in progressively more offshore habitats throughout the season (mean $\delta^{13} \mathrm{C}$ values $=-17.6 \%$ prior to laying and $-19.2 \%$ during chick-rearing). Like Cassin's auklets, rhinoceros auklets fed at an intermediate trophic level prior to laying (mean $\delta^{15} \mathrm{~N}$ value $=13.5 \%$ ), but, unlike Cassin's auklets, at progressively higher trophic levels during incubation (mean $\delta^{15} \mathrm{~N}=13.9 \%$ ) and chick-rearing $\left(\right.$ mean $\delta^{15} \mathrm{~N}$ value $=14.6 \%$ ) and with no consistent shift in habitat types. Trophic and habitat shifting was most evident in tufted puffins. This species fed at low trophic levels during the prelaying and incubation periods (mean $\delta^{15} \mathrm{~N}$ value $=12.3$ and $12.5 \%$, respectively), but at a much higher trophic level (mean $\delta^{15} \mathrm{~N}$ value $=14.1 \%$ ) while provisioning chicks. While provisioning, puffins also fed in more near-shore or benthic habitats than they had earlier (mean $\delta^{13} \mathrm{C}$ value $\leq 19.5 \%$ early, but $\delta^{13} \mathrm{C}=-18.8 \%$ later).

In 3 species (common murres, Cassin's auklets and rhinoceros auklets) combined $\delta^{15} \mathrm{~N}$ and $\delta^{13} \mathrm{C}$ values differed significantly between provisioning adults and their nestlings (Wilks' lambda $\leq 0.566$, all $F \geq 11.14$, all $p<0.003)$. However, there was no common pattern of difference in parent-offspring isotopic values across the 3 species (Fig. 1). In contrast, there was very little difference in combined $\delta^{15} \mathrm{~N}$ and $\delta^{13} \mathrm{C}$ values between provisioning tufted puffins and their nestlings (Wilks' lambda $=0.94, F_{2,27}=0.86, p=0.43$ ). No comparison was possible for pigeon guillemots.

\section{Seabird community-level analyses}

Based on combined $\delta^{15} \mathrm{~N}$ and $\delta^{13} \mathrm{C}$ values across all breeding stages, this community of 5 species of alcids shifted from low to mid-trophic level feeding early in the season to mid- to high trophic level feeding later (Fig. 2). Four of the 5 species: common murre, pigeon guillemot, rhinoceros auklet and tufted puffin, converged at high $\delta^{15} \mathrm{~N}$ values while provisioning 

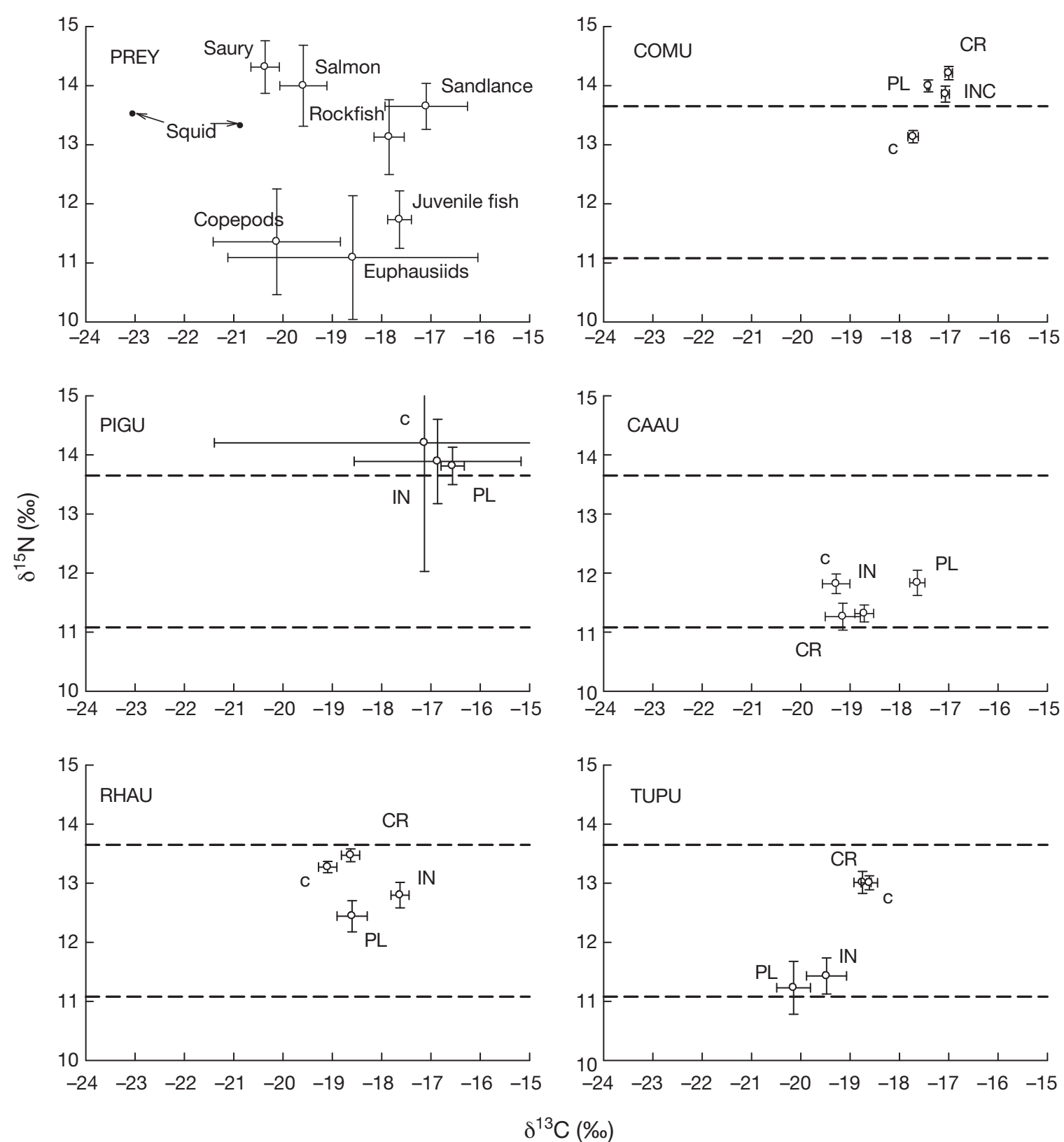

Fig. 1. Stable isotopic values (mean $\pm \mathrm{SD}, \delta^{15} \mathrm{~N}$ and $\delta^{13} \mathrm{C}$ ) of reference prey items fed to Cassin's and rhinoceros auklet nestlings and of tissues in 5 species of alcids (COMU: common murre; PIGU: pigeon guillemot; CAAU: Cassin's auklet; RHAU: rhinoceros auklet; TUPU: tufted puffin, for taxonomic names see Table 1) after correction for diet-tissue isotopic discrimination. For seabird tissues codes: PL, adult blood taken during the prelaying period; IN, adult blood taken during incubation; CR, adult blood taken during provisioning; c, nestling blood. For reference, mean $\delta^{15} \mathrm{~N}$ values for euphausiids (lower dashed line) and Pacific sandlance (upper dashed line) are superimposed on the seabird figures

nestlings late in the breeding season, after the more zooplanktivorous Cassin's auklet had completed its breeding season (Fig. 2). In contrast, there was no seasonal shift towards either more inshore or offshore habitats across the community. A detailed statistical analysis is precluded by the many possible factors (species, stages and tissues) and interactions.
We sampled blood from nestlings of all 4 of these lateseason, high-trophic level species within a relatively narrow time period ( $<10 \mathrm{~d}$; Fig. 2) and found highly significant differences among them in their combined $\delta^{15} \mathrm{~N}$ and $\delta^{13} \mathrm{C}$ values (Wilks' lambda $=0.08, F_{2,3,27}=40.45, \mathrm{p}<$ 0.0001). Overlap only appeared between nestlings of the 2 puffin species, rhinoceros auklet and tufted puffins. 


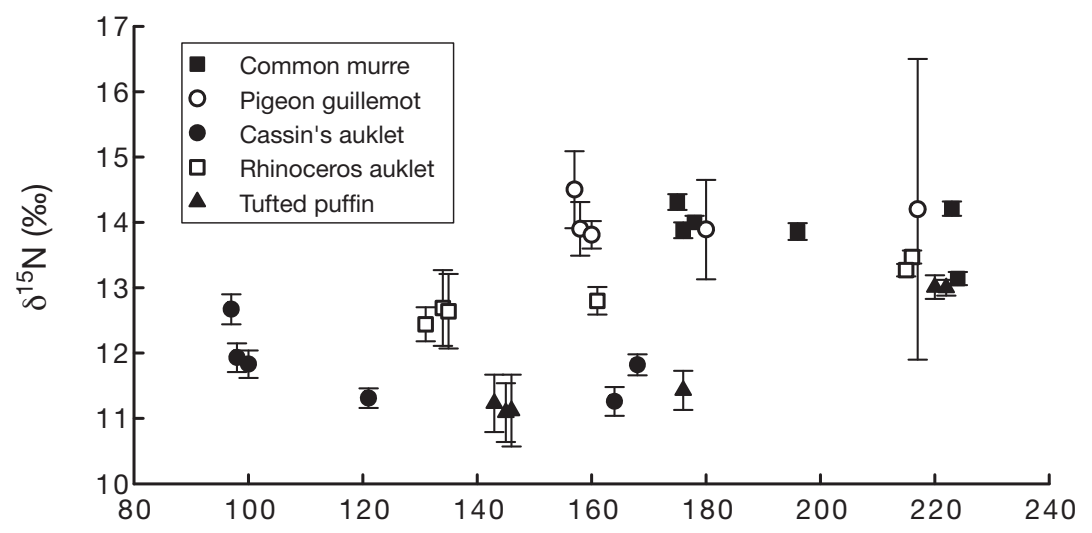

was no pattern in the trophic and habitat shifting common to all species, but the alcid community at Triangle Island as a whole exhibited a seasonal trophic shift, from low to mid-trophic level feeding early (zooplankton and mixed zooplankton and fish diets), to mid- to high trophic level feeding late (fish diets), though with no corresponding shift in foraging habitat.

Our field-derived estimates of diettissue $\delta^{15} \mathrm{~N}$ discrimination factors were $+1.5 \%$ for Cassin's auklets and $+0.6 \%$ for rhinoceros auklets, values consid-

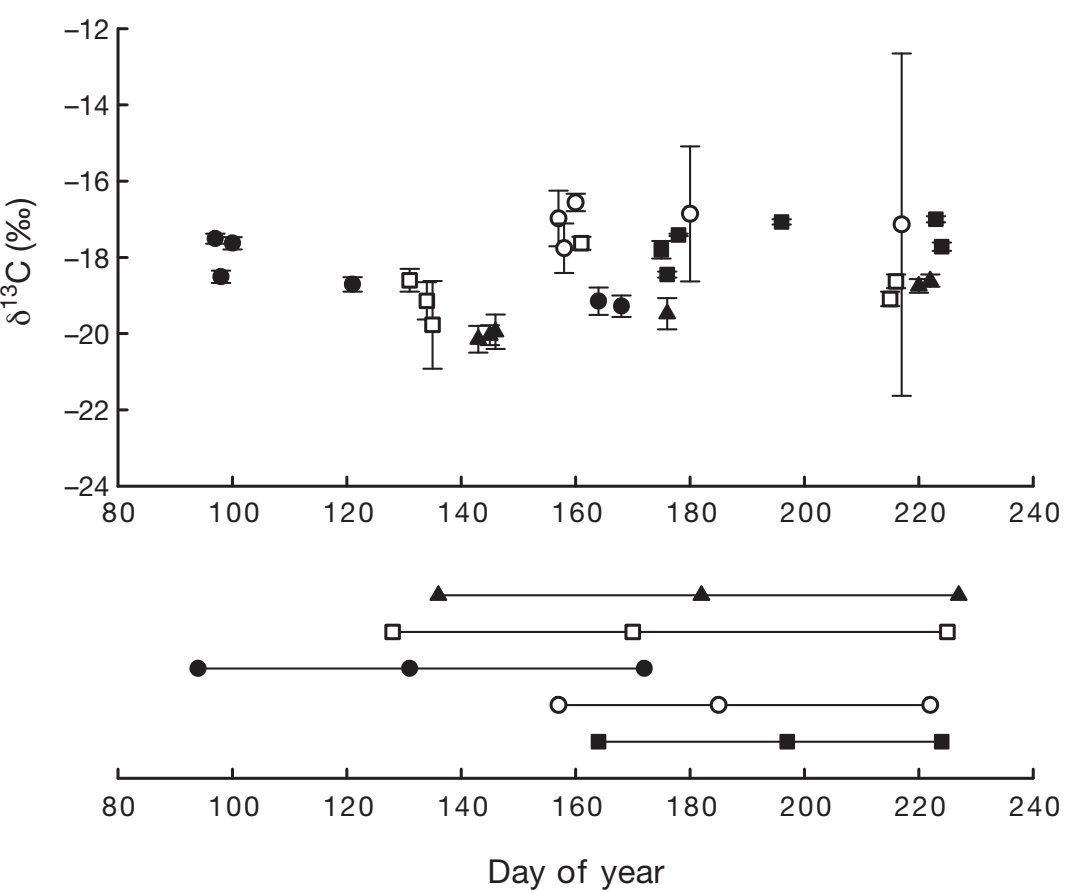

Fig. 2. Diet-tissue discrimination-corrected stable isotopic values $\left(\delta^{15} \mathrm{~N}\right.$, upper panel; $\delta^{13} \mathrm{C}$, lower panel) of tissues from all 5 alcid species (for taxonomic names see Table 1) in relation to the day of the year on which they were collected. Data points below panels are median dates of egg-laying, hatching and fledging for the 5 alcids in 2002; lines thus represent the incubation periods and the offspring-provisioning periods

erably smaller than the 2 to $4 \%$ typically reported for birds (Dalerum \& Angerbjörn 2005). There is increasing awareness that many factors affect isotopic diet-tissue discrimination factors (Quillfeldt et al. 2008). As such, a single discrimination factor applied to all seabirds of both age groups is almost certainly unrealistic. Nonetheless, we consider our approach using contemporary data of diet and blood isotope values at our study site to be the most appropriate option available to us and certainly better than application of 'textbook' values.

\section{Species-level analyses}

Common murre and pigeon guillemot

At all breeding stages, common murres Uria aalge and pigeon guillemots Cepphus columba fed on high trophic level prey (fish) captured in inshore or benthic habitats. They were the only species to display such general consistency in diet and foraging habitat. Adult common murres provisioned nestlings with prey from a

\section{DISCUSSION}

We found that combined $\delta^{15} \mathrm{~N}$ and $\delta^{13} \mathrm{C}$ values differed significantly among breeding stages in adult common murres Uria aalge, Cassin's auklets Ptychoramphus aleuticus, rhinoceros auklets Cerorhinca monocerata and tufted puffins Fratercula cirrhata. These species demonstrably altered their diets and habitats through the season. Diets of provisioning adults differed from those fed to nestlings they provisioned in all species except the tufted puffin. There lower mean trophic level than they ate themselves, although this pattern is not universal in murres. Of note, diets fed to common murre nestlings inferred from SIA corresponded quite well with observed diets at Triangle Island, which consist mainly (70 to $80 \%$ ) of adult Pacific sandlance and juvenile rockfish (Hipfner \& Greenwood 2008). Likewise, isotopic values in pigeon guillemot nestlings at Triangle Island were consistent with those from diets at the Farallon Islands, California, which consist of juvenile rockfish and benthic fish (Ainley \& Boekelheide 1990). 
The pigeon guillemot is generally considered to be an inshore, benthic fish specialist (Gaston \& Jones 1998), and our single year's SIA results, like those at the Farallones (Sydeman et al. 1997), are consistent with this view. Likewise, throughout their range, common murre breeding colonies are strongly associated with shallow, continental shelf waters, and the species appears to be well adapted morphologically to diving deeply while pursuing and capturing fish (Gaston \& Jones 1998). Our SIA results are consistent with those observations as well.

Based on at-sea distributions spanning many years, it appears that murres are quite flexible in their prey and choice of foraging habitats (Yen et al. 2004). Thus, while fish caught in nearshore habitats may be primary prey for breeding common murres, especially while provisioning nestlings, lower trophic level prey can be important at some colonies, perhaps related to local oceanography and the availability of fish (Thompson et al. 1999, Ainley et al. 2002). On the whole, it is apparent that common murres exhibit greater flexibility in their foraging ecology than is reflected in our single year's isotopic data.

\section{Cassin's auklet}

This species is widely thought to be an obligate offshore zooplanktivore (Yen et al. 2004), although little information exists on adult rather than nestling diets (Abraham \& Sydeman 2004). Whereas SIA at the Farallones found that auklets fed consistently at low trophic levels (Sydeman et al. 1997), isotopic values from Triangle Island indicated that Cassin's auklets ate both fish and crustaceans captured in relatively inshore or benthic waters early in the breeding season (March and April). Cassin's auklets generally form eggs well ahead of the annual peak in zooplankton biomass, which occurred in early May of 2002 off the British Columbia coast (Mackas et al. 2007). Feeding at a mixed trophic level might be an important early season strategy by which Cassin's auklets meet nutritional requirements in phenologically late years.

Later, however, during incubation and provisioning, Cassin's auklets foraged at lower trophic levels and in more offshore or pelagic habitats. This seasonal shift occurs consistently at Triangle Island and probably reflects movements to foraging areas along the continental shelf break 25 to $40 \mathrm{~km}$ to the west where Stage C5 Neocalanus cristatus copepedites form a profitable food source during May and June (Boyd et al. 2008, Hipfner 2008). Studies elsewhere also show that Cassin's auklets will tend to use the same foraging areas repeatedly, if they happen to be consistently productive (Adams et al. 2004).
As found in several other species, isotopic values suggest that adult Cassin's auklets fed prey items from a higher trophic level to their nestlings than they ate themselves. Our methods for estimating discrimination factors ensured close correspondence between $\delta^{15} \mathrm{~N}$ values in Cassin's auklet nestlings and their prey, which consist primarily of crustaceans and ichthyoplankton at Triangle (Hedd et al. 2002, Hipfner 2008) and elsewhere (Abraham \& Sydeman 2004, Adams et al. 2004).

\section{Rhinoceros auklet}

Widely categorized as piscivores (Thayer \& Sydeman 2007), a view supported by a single season's SIA at the Farallones (Sydeman et al. 1997), rhinoceros auklets breeding at Triangle Island shifted from intermediate trophic level feeding early in the season (a mixed diet including both fish and zooplankton), to higher trophic level feeding (fish, squid) while raising nestlings. However, they exhibited no consistent movements either towards more inshore or offshore habitats. Diets at Triangle Island include a wide range of epipelagic fish caught in inshore (Pacific sandlance, juvenile rockfish) and offshore (Pacific saury, salmon, with occasional squid; Hedd et al. 2006) waters, as they do elsewhere (Thayer et al. 2008).

The rhinoceros auklet's wide range in prey items and foraging habitats, as well as the differences in the isotopic values in adults and nestlings (see also Davoren \& Burger 1999), might be consequences of their single, nocturnal provisioning habits. These habits potentially free them to forage over larger areas than might be possible in diurnal species, such as the tufted puffins, which provision their offspring more than once per day (Vermeer 1979). Nocturnal habits also might free rhinoceros auklets to forage exclusively for themselves during the day, before capturing exclusively large, energetically rich prey late in the day to deliver to nestlings (Davoren \& Burger 1999).

\section{Tufted puffin}

Of the 5 species in our study, tufted puffins made the most pronounced trophic shift across the 3 breeding stages. Prior to laying and during incubation, adult puffins fed on lower trophic level prey obtained in more offshore or pelagic habitats than any of the other alcid species. In fact, this species is considered the most pelagic of the alcids (Piatt \& Kitaysky 2002). During provisioning, however, adult birds shifted to feeding themselves and their nestlings on higher trophic level prey, which they obtained in more inshore or 
benthic habitats. The upward trophic shifting appears to be a regular occurrence in this species at Triangle Island (Hipfner et al. 2007).

Tufted puffin was the only species of the 5 alcid species in our study to show close correspondence in $\delta^{15} \mathrm{~N}$ and $\delta^{13} \mathrm{C}$ values in adults and nestlings. Interestingly, Piatt \& Kitaysky (2002) concluded that squid were very important in adult, but not in nestling, diets across Alaska, while Baird (1991) proposed that adult puffins delivered larger, more energy-rich items to nestlings than they ate themselves. Likewise, Hobson et al. (1994) placed adult tufted puffins at a relatively low trophic level during the breeding season despite evidence that nestlings were fed fish. The $\delta^{15} \mathrm{~N}$ values in nestlings were consistent with their observed diets at Triangle, which consisted largely of Pacific sandlance and juvenile rockfish (Vermeer 1979).

\section{Community-level stable isotopic analyses}

Our alcid community exhibited a clear temporal trophic shift: early in the season (March through May), foraging was directed at low (by tufted puffin) or low to mid- (by Cassin's auklet, rhinoceros auklet) trophic level prey, but later (June through August) at mid- to high trophic level prey (by common murre, pigeon guillemot, rhinoceros auklet and tufted puffin). Even in the more zooplanktivorous Cassin's auklets, fish often becomes important in nestling diets late in their breeding season (June and July; Ainley \& Boekelheide 1990). However, the community shift in trophic level occurred without a corresponding shift towards either more inshore or offshore feeding, consistent with the lack of strong association between $\delta^{15} \mathrm{~N}$ and $\delta^{13} \mathrm{C}$ values in prey items. This suggests that any trophic level increase in $\delta^{13} \mathrm{C}$ values was swamped by the much larger spatial effect of inshore (benthic) versus offshore (pelagic) signals.

The tendency to converge on fish feeding late in the breeding season occurs in other alcid-based seabird communities (Ainley \& Boekelheide 1990, Hatch \& Hatch 1990). Our study complements those studies because it includes concurrent isotopic measurements of adult and nestling trophic position, which indicate that both nestlings and adults fed on high trophic level prey late in the breeding season. That general pattern: relying on lower trophic levels early and higher trophic levels late, likely mirrors the temporal flow of energy through the marine ecosystem, whereby the pulse in lower trophic level biomass progressively results in later pulses in higher trophic level biomass (Levinton 2001).

A high degree of trophic overlap has been reported in other seabird communities (Forero et al. 2004).
Given that many species in these communities time their breeding so that they raise nestlings on the same or similar resources simultaneously, competition does not seem to be the primary force structuring these communities (Ainley \& Boekelheide 1990, Hatch \& Hatch 1990, Forero et al. 2004). In fact, at Triangle, the 4 species that feed fish to their nestlings have very high overlap in species composition of their diets, with Pacific sandlance and juvenile rockfish (a mix of species) being important (Vermeer 1979, Hedd et al. 2006, Hipfner \& Greenwood 2008). However, we found very little overlap in combined $\delta^{15} \mathrm{~N}$ and $\delta^{13} \mathrm{C}$ values in the nestlings of the 4 species that were fed fish concurrently, which indicates that these species might be finely, rather than overtly, segregated in their foraging habits at that time.

Finally, we note that our results, like those of previous studies (e.g. Ainley \& Boekelheide 1990), provide indirect support for robust paradigms concerning the evolution of the timing of avian breeding (Lack 1954). These propose that birds ultimately time their breeding so that the period of greatest energetic demand, nestling rearing, coincides with the seasonal period of maximum availability of food suitable for provisioning offspring. Despite the high overlap in nestling diets, however, we found evidence that these alcid species may be ecologically segregated at fine scales.

Acknowledgements. We thank the 2002 Triangle field crew for top-notch assistance with the field work. Funding was provided by a grant from the 'Nestucca' Oil Spill Trust Fund to D. Bertram and G. Kaiser; the Centre for Wildlife Ecology; the World Wildlife Fund Canada (through the Endangered Species Recovery Fund); and the Science Horizons program of Environment Canada. As in previous years, we received invaluable ship and helicopter support from the Canadian Coast Guard. Thanks also to Judy Higham and Connie Smith for logistical support of our field camp from back home in Vancouver.

\section{LITERATURE CITED}

Abraham CL, Sydeman WJ (2004) Ocean climate, euphausiids and auklet nesting: interannual trends and variation in phenology, diet and growth of a planktivorousseabird Ptychoramphus aleuticus. Mar Ecol Prog Ser 274:235-250

Adams J, Takekawa JY, Carter HR (2004) Stable foraging areas and variable chick diet in Cassin's auklets (Ptychoramphus aleuticus) off southern California. Can J Zool 82:1578-1595

Ainley DG, Boekelheide RJ (1990) Seabirds of the Farallon Islands: ecology, dynamics and structure of an upwellingsystem community. Stanford University Press, Stanford, CA

Ainley DG, Nettleship DN, Carter HR, Storey AE (2002) Common murre Uria aalge. In: Poole A, Gill F (eds) The birds of North America, No 666. The Birds of North America, Philadelphia, PA, p 1-44

Baird PH (1991) Optimal foraging and intraspecific competition in the tufted puffin. Condor 93:503?515 
Boyd S, McFarlane-Tranquilla L, Ryder JL, Shisko SG, Bertram DF (2008) Variation in marine distributions of Cassin's auklets breeding at Triangle Island, British Columbia. Auk 125:158-166

Cherel Y, Hobson KA, Weimerskirch H (2005) Using stable isotopes to study resource acquisition and allocation in procellariiform seabirds. Oecologia 145:533-540

Cherel Y, Le Corre M, Jacquemet S, Menard F, Richard P, Weimerskirch H (2008) Resource partitioning within a tropical seabird community: new information from stable isotopes. Mar Ecol Prog Ser 366:281-291

- Dalerum F, Angerbjörn A (2005) Resolving temporal variation in vertebrate diets using naturally occurring stable isotopes. Oecologia 144:647-658

Davies WE (2007) Reproductive foraging ecology of five sympatrically breeding alcid seabirds. MSc thesis, Simon Fraser University, Burnaby, BC

Davoren GK, Burger AE (1999) Differences in prey selection and behaviour during self-feeding and chick provisioning in rhinoceros auklets. Anim Behav 58:853-863

Edwards M, Richardson AJ (2004) Impact of climate change on marine pelagic phenology and trophic mismatch. Nature 430:881-884

Forero MG, Tella JL, Hobson KA, Bertellotti M, Blanco G (2002) Conspecific food competition explains variability in colony size: a test in magellanic penguins. Ecology 83: 3466-3475

Forero MG, Bortolotti GR, Hobson KA, Donazar JA, Bertelloti M, Blanco G (2004) High trophic overlap within the seabird community of Argentinean Patagonia: a multiscale approach. J Anim Ecol 73:789-801

$>$ Forero MG, Gonzalez-Solis J, Hobson KA, Donazar JA, Bertellotti M, Blanco G, Bortolotti GR (2005) Stable isotopes reveal trophic segregation by sex and age in the southern giant petrel in two different food webs. Mar Ecol Prog Ser 296:107-113

Gaston AJ, Jones IL (1998) The auks. Oxford University Press, Oxford

- Hatch SA, Hatch MA (1990) Breeding seasons of oceanic birds in a subarctic colony. Can J Zool 68:1664-1679

$>$ Hedd A, Ryder JL, Cowen LL, Bertram DF (2002) Inter-annual variation in the diet, provisioning and growth of Cassin's auklet at Triangle Island, British Columbia: responses to variation in ocean climate. Mar Ecol Prog Ser 229:221-232

$>$ Hedd A, Bertram DF, Ryder JL, Jones I (2006) Effects of interdecadal climate variability on marine trophic interactions: rhinoceros auklets and their fish prey. Mar Ecol Prog Ser 309:263-278

Hipfner JM (2008) Matches and mismatches: ocean climate, prey phenology and breeding success in a zooplanktivorous seabird. Mar Ecol Prog Ser 368:295-304

> Hipfner JM, Greenwood JL (2008) Breeding biology of the common murre at Triangle Island, British Columbia, Canada, 2002-2007. Northwest Naturalist 89:76-84

> Hipfner JM, Charleton K, Davies WE (2004) Rates and consequences of relaying in Cassin's auklets Ptychoramphus aleuticus and rhinoceros auklets Cerorhinca monocerata breeding in a seasonal environment. J Avian Biol 35: 224-236

Hipfner JM, Charete MC, Blackburn GS (2007) Subcolony variation in breeding success in the tufted puffin, its asso-

Editorial responsibility: Rory Wilson,

Swansea, UK ciation with foraging ecology and its implications. Auk 124:1149-1157

Hobson KA, Piatt JF, Pitocchelli J (1994) Using stable isotopes to determine seabird trophic relationships. J Anim Ecol 63: 786-798

Hodum PJ, Hobson KA (2000) Trophic relationships among Antarctic fulmarine petrels: insights into dietary overlap and chick provisioning strategies inferred from stableisotope $\left(\mathrm{d}^{15} \mathrm{~N}\right.$ and $\left.\mathrm{d}^{13} \mathrm{C}\right)$ analyses. Mar Ecol Prog Ser 198: 273-281

- Kelly JK (2000) Stable isotopes of carbon and nitrogen in the study of avian and mammalian trophic ecology. Can J Zool 78:1-27

Lack D (1954) Natural regulation of animal numbers. Clarendon Press, London

Levinton JS (2001) Marine biology: function, biodiversity, ecology. Oxford University Press, New York

Mackas DL, Batten S, Trudel M (2007) Effects on zooplankton of a warmer ocean: recent evidence from the Northeast Pacific. Prog Oceanogr 75:223-252

Piatt JF, Kitaysky AS (2002) Tufted puffin Fratercula cirrhata. In: Poole A, Gill F (eds) The birds of North America, No 708. The Birds of North America, Philadelphia, PA, p 1-32

Quillfeldt P, Bugoni L, McGill RAR, Masello JF, Furness RW (2008) Differences in stable isotopes in blood and feathers of seabirds are consistent across species, age and latitude: implications for food web studies. Mar Biol 155: 593-598

> Quillfeldt P, McGill RAR, Furness RW (2005) Diet and foraging areas of Southern Ocean seabirds and their prey inferred from stable isotopes: review and case study of Wilson's storm-petrel. Mar Ecol Prog Ser 295:295-304

Rodway MS (1991) Status and conservation of breeding seabirds in British Columbia. In: Croxall JP (ed) Supplement to the status and conservation of the world's seabirds. International Council for Bird Preservation, Cambridge, p 43-102

Sydeman WJ, Hobson KA, Pyle P, MacLaren EB (1997) Trophic relationships among seabirds in central California: combined stable isotope and conventional diet approach. Condor 99:327-336

Thayer JA, Sydeman WJ (2007) Spatio-temporal variability in prey harvest and reproductive ecology of a piscivorous seabird, Cerorhinca monocerata, in an upwelling system. Mar Ecol Prog Ser 329:253-265

- Thayer JA, Bertram DF, Hatch SA, Hipfner JM, Slater L, Watanuki Y, Sydeman WJ (2008) Forage fish of the Pacific Rim as revealed by the diet of a piscivorous seabird: synchrony and relationships with sea surface temperature. Can J Fish Aquat Sci 65:1610-1622

Thompson DR, Lilliendahl K, Solmundsson J, Furness RW, Waldron S, Phillips RA (1999) Trophic relationships among six species of Icelandic seabirds as determined through stable isotope analysis. Condor 101:898-903

- Vermeer K (1979) A provisional explanation of the reproductive failure of tufted puffins Lunda cirrhata on Triangle Island, British Columbia. Ibis 121:348-354

Yen P, Sydeman WJ, Hyrenbach KD (2004) Marine bird and cetacean associations with bathymetric habitats and shallow water topographies: implications for trophic transfer and conservation. J Mar Syst 50:79-99

Submitted: November 22, 2007; Accepted: March 5, 2009 Proofs received from author(s): April 24, 2009 